\title{
Heparin coating of an extracorporeal circuit partly improves hemostasis after cardiopulmonary bypass
}

\begin{abstract}
Heparin coating of an extracorporeal circuit for cardiopulmonary bypass improves the hemocompatibility of the circuit and reduces the inflammatory response of the body. It has not been established, however, that heparin coating also improves postoperative hemostasis. We therefore performed a study in 30 patients who underwent a routine coronary artery bypass graft operation subjected to cardiopulmonary bypass with an uncoated (control) or a heparin-coated extracorporeal circuit (Duraflo II). We found significantly higher plasma levels of heparin in the Duraflo II group. However, we found no significant differences between the two groups with regard to other parameters of activation of the fibrinolytic and coagulation systems and to activation of platelets. Postoperative blood loss and donor blood transfusions were reduced in the Duraflo II group but not to a statistically significant extent. We conclude that heparin coating of an extracorporeal circuit improves anticoagulation but does not significantly reduce platelet activation, fibrinolysis, postoperative blood loss, and donor blood transfusions in routine coronary bypass operations. (J THORAC CaRdiovasc SuRG 1994;107:289-92)
\end{abstract}

P. W. Boonstra, MD, PhD, Y. J. Gu, MD, PhD, C. Akkerman, BSc, J. Haan, BSc, $\mathrm{R}$. Huyzen, MD, and W. van Oeveren, PhD, Groningen, The Netherlands

$\mathrm{C}$ ardiopulmonary bypass (CPB) activates both formed blood elements and humoral systems and thereby causes a systemic inflammatory response..$^{1-3}$ This inflammatory response can be reduced by heparin coating of the surface of the extracorporeal circuit (ECC).${ }^{4,5}$ Coating of the surface of an ECC with heparin improves the hemocompatibility by thrombin binding and inactivation. ${ }^{6-9}$ However, for hemostasis to be preserved, platelet activation and fibrinolytic activity also have to be reduced. In the present study we tested the hypothesis that heparin coating can also reduce platelet activation and fibrinolytic activity and as a consequence can lead to an improved postoperative hemostasis in routine coronary artery bypass graft (CABG) operations. Therefore we investigated the activation and consumption of blood compo-

From the Thorax Centre, University Hospital of Groningen, Oostersingel 59, Groningen, The Netherlands.

Supported by a grant from Bentley/Baxter, Inc., Uden, The Netherlands.

Received for publication Feb. 2, 1993.

Accepted for publication May 24, 1993.

Address for reprints: W. van Oeveren, PhD, Thorax Centre, Department of Cardiopulmonary Surgery, University Hospital of Groningen, Oostersingel 59, 9713 EZ Groningen, The Netherlands.

Copyright $(1994$ by Mosby-Year Book, Inc.

$0022-5223 / 94 \$ 1.00+.10 \quad 12 / 1 / 49613$ nents that are indicative for alteration in the hemostatic capacity in a study on 30 patients randomly allocated to heparin-coated or uncoated (control) devices. The clinical impact of the effects of heparin coating was assessed by measuring postoperative bleeding time, total amount of blood loss, and donor blood transfusions.

\section{Methods}

Patients. The study was conducted in 30 patients who underwent an elective CABG operation with saphenous vein or internal mammary arteries (or both). These patients were less than 75 years of age, had no evidence of severe heart failure or renal or liver dysfunction, had no bleeding diathesis, did not have diabetes mellitus, had not used platelet-inhibiting drugs within 10 days before the operation, and had given informed consent. The study was approved by the medical ethical committee of our institution and was conducted in the Department of Thoracic Surgery of the University Hospital of Groningen.

The patients were randomly assigned for $\mathrm{CPB}$ with or without a heparin-coated ECC. After premedication of the patient with diazepam ( 10 to $15 \mathrm{mg}$ ), anesthesia was induced with sufentanyl ( 3 to $5 \mu \mathrm{g} / \mathrm{kg}$ ) and muscle relaxation was achieved with pancuronium (100 to 140 $\mu \mathrm{g} / \mathrm{kg}$ ). Ventilation was controlled with air in oxygen. Analgesia was provided with sufentanyl and midazolam 
Table I. Clinical characteristics of the patient groups

\begin{tabular}{lcc}
\hline & $\begin{array}{c}\text { Duraflo II } \\
(n=15)\end{array}$ & $\begin{array}{c}\text { Control } \\
(n=15)\end{array}$ \\
\hline Age (yr) & $62 \pm 3$ & $59 \pm 3$ \\
Weight (kg) & $79 \pm 2$ & $80 \pm 3$ \\
No. of anastomoses & $3.5 \pm 0.4$ & $3.9 \pm 0.4$ \\
Bypass time (min) & $86 \pm 5$ & $103 \pm 10$ \\
Crossclamp time (min) & $49 \pm 4$ & $67 \pm 12$ \\
\hline
\end{tabular}

Data are means \pm standard errors of the mean. There were no statistically significant differences between the two groups.

infusion. The antibiotic cefamandole was administered before the operation in a dosage of 2 gm intravenously 4 times daily up to 48 hours after the start of the operation. Dexamethasone $(1 \mathrm{mg} / \mathrm{kg})$ was administered 30 minutes before the operation. ${ }^{10} \mathrm{After}$ a median sternotomy, bovine lung heparin $(300 \mathrm{IU} / \mathrm{kg})$ was administered. Heparinization was checked by the activated clotting time, which had to be kept between 400 and 800 seconds during CPB.

CPB. Except for the cardiotomy reservoir, all components of the ECC were coated with heparin (Duraflo II, Bentley/Baxter Inc., Uden, The Netherlands). The ECC consisted of roller pumps and a membrane oxygenator (CM-50, Bentley/Baxter), a Bentley cardiotomy reservoir, and polyvinylchloride tubing, except for the pump tubing, which was silicone rubber. The ECC was primed with a gelatin-containing crystalloid solution (Gelifundol, Biotest Pharma GmbH, Dreieck, Germany) and contained $1500 \mathrm{IU}$ of bovine heparin. CPB was performed with cardioplegic arrest and hypothermia $\left(27^{\circ} \mathrm{C}\right.$ nasopharyngeal temperature) with pump flows of $2.4 \mathrm{~L} / \mathrm{m}^{2}$ per minute and maintenance of mean arterial blood pressures of 50 to $60 \mathrm{~mm} \mathrm{Hg}$. After CPB heparin was neutralized by means of protamine chloride $(3 \mathrm{mg} / \mathrm{kg}$, Hoffmann-laRoche bv, Mijdrecht, The Netherlands).

Measurements. Bleeding time was measured according to the method described by Ivy, Nelson, and Bucher ${ }^{11}$ on the day before the operation and 3 hours after arrival of the patient in the intensive care unit. During the operation blood samples were collected six times; after induction of anesthesia, 5 minutes before the start of $\mathrm{CPB}$, after 5 minutes of $\mathrm{CPB}$, just before release of the aortic crossclamp, at the end of $\mathrm{CPB}$, and 20 minutes after protamine chloride administration. Platelet count and hematocrit value from citrated blood were measured by a cell counter (Cell-Dyn 610; Sequoia-Turner, Mountain View, Calif.). For biochemical assays, plasma was obtained by centrifuging whole blood in a chilled centrifuge at $1000 \mathrm{~g}$ for 10 minutes. Plasma heparin concentrations were measured by factor Xa inhibition by chromogenic assay (Kabi Diagnostica, Stockholm, Sweden) from the priming solution of the ECC and from plasma anticoagulated with
Table II. Postoperative donor blood transfusions

\begin{tabular}{ccc}
\hline Groups & $\begin{array}{c}F F P \\
\text { (units) }\end{array}$ & $\begin{array}{c}\text { RBC } \\
\text { (units) }\end{array}$ \\
\hline Duraflo $(n=13)$ & $0.69(0-2)$ & $0.31(0-2)$ \\
Control $(n=14)$ & $1.21(0-4)$ & $0.79(0-2)$ \\
\hline
\end{tabular}

Data are mean values with ranges in parentheses. $F F P$, Fresh frozen plasma; $R B C$, red blood cells. There were no statistically significant differences between the two groups.

citrate. Plasma with aprotinin-hirudin-citrate medium was prepared to determine fibrin degradation products (enzyme-linked immunosorbent assay, Organon Teknika, Turnhout, Belgium) and fibrinopeptide A concentrations (radioimmunoassay, Mallinckrodt, St. Louis, Mo.). Blood $(2.5 \mathrm{ml})$ was collected into $\beta$-thromboglobulin collecting tubes to determine plasma $\beta$-thromboglobulin concentrations with radioimmunoassay (Amersham, Amersham, United Kingdom), and plasma with indomethacin-citrate medium was used for determination of thromboxane $\mathrm{B}_{2}$ concentrations (enzyme immunoassay, Cayman Chemical Co., Ann Arbor, Mich.). Postoperative blood loss through chest tube drainage and postoperative donor blood transfusions were measured up to 18 hours after the end of CPB.

Statistics. Values for biochemical tests from blood samples obtained during CPB were corrected for hemodilution by the prebypass hematocrit levels, except for heparin concentrations. Statistical analysis was performed by Student's $t$ test. Results were expressed as mean \pm standard error of the mean and a $p$ value of less than 0.05 was considered to be significant.

\section{Results}

Patients in the two groups did not differ significantly in regard to age, body weight, number of anastomoses, bypass time, and aortic crossclamp time (Table I). Plasma heparin concentrations decreased immediately after the start of CPB because of dilution with the pump prime and decreased further in the control group but not in the Duraflo II group. Thus heparin concentrations were significantly higher in the Duraflo II group at the end of bypass (Fig. 1). Notably, we found $0.1 \pm 0.05 \mathrm{IU} / \mathrm{ml}$ of heparin in the priming solution of the Duraflo II circuit before heparin was introduced.

Levels of fibrin degradation products were low and stable during aortic crossclamping but increased significantly thereafter to ten times the prebypass levels $(11,840 \pm 2,990 \mathrm{ng} / \mathrm{ml}$ in the Duraflo II group and $11,360 \pm 2,310 \mathrm{ng} / \mathrm{ml}$ in the control group). No significant differences were observed between the two groups.

Fibrinopeptide A concentrations remained low during the operation in both groups; in particular, during the 
heparinization period almost no fibrinopeptide $\mathrm{A}$ was generated (highest levels were $6.3 \pm 1.4 \mathrm{ng} / \mathrm{ml}$ in the Duraflo II group and $6.8 \pm 2.0 \mathrm{ng} / \mathrm{ml}$ in the control group). No significant differences were observed between the two groups.

Platelet count increased slightly after the start of CPB in both groups (highest values were $147 \% \pm 10 \%$ of baseline in the Duraflo II group and $163 \% \pm 45 \%$ of baseline in the control group) and remained stable thereafter. After administration of protamine chloride the platelet count decreased in both groups $(129 \% \pm 10 \%$ in the Duraflo II group and $138 \% \pm 35 \%$ in the control group). We found no significant differences between the two groups.

After the operation the bleeding time appeared to be increased similarly in the two groups-from 6.6 to 10.5 minutes in the control group and from 7.5 to 11.0 minutes in the Duraflo II group. Differences between the two groups were not significant.

$\beta$-Thromboglobulin increased significantly and progressively during $\mathrm{CPB}$ in both groups, the highest values being reached at the end of CPB $(1910 \pm 310 \mathrm{ng} / \mathrm{ml}$ in the Duraflo II group and $1810 \pm 280 \mathrm{ng} / \mathrm{ml}$ in the control group). We found no significant differences between the two groups.

After the start of CPB thromboxane $B_{2}$ increased slightly. After aortic crossclamping, however, a steep increase was found in both groups (highest values were $114 \pm 10 \mathrm{ng} / \mathrm{ml}$ in the Duraflo II group and $104 \pm 16$ $\mathrm{ng} / \mathrm{ml}$ in the control group). Differences between the two groups were not significant.

No statistically significant differences in blood loss and donor blood transfusions were observed between the two groups, although blood loss was somewhat lower in the Duraflo group ( $709 \pm 101 \mathrm{ml}$ in the Duraflo group versus $931 \pm 136 \mathrm{ml}$ in the control group).

In both groups one patient was excluded from the evaluation of blood loss and donor blood transfusions because of bleeding necessitating a rethoracotomy. One additional patient from the Duraflo II group was excluded because of the possibility of protamine chloride hypersensitivity (Table II).

\section{Discussion}

Heparin coating of the ECC appeared to prevent the reduction of plasma heparin levels. This could be explained by reduced activation of the clotting system and reduced consumption of heparin or by leaching of surface-bound heparin during CPB. Furthermore, we found that reduction of thrombin activity by heparin coating, which has been reported previously, ${ }^{6,7}$ was insufficient to preserve hemostasis during $\mathrm{CPB}$, as indicated by a small

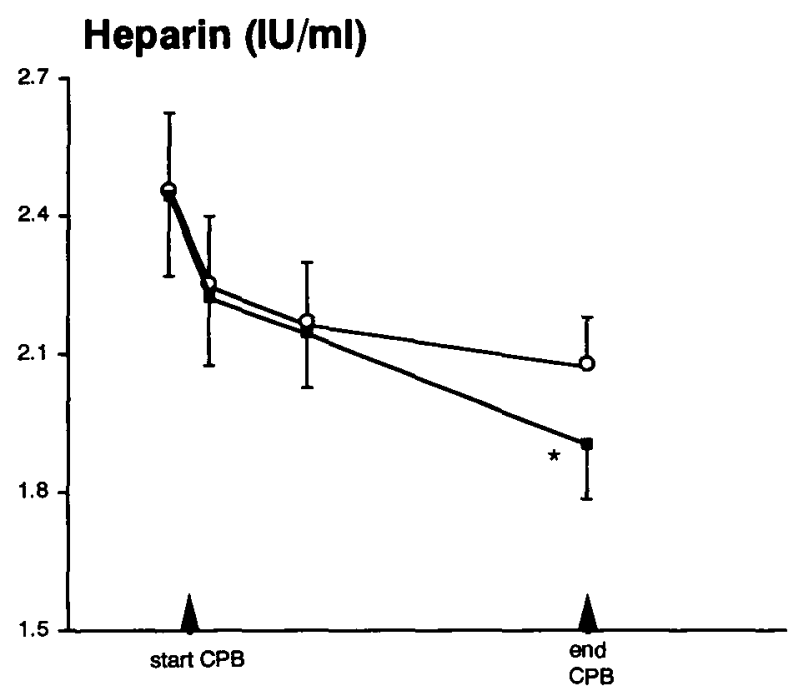

Fig. 1. Mean plasma heparin concentration, measured by factor Xa inhibition in plasma, was significantly higher in the Duraflo II group at the end of CPB. Closed squares indicate the control group and open circles the Duraflo II group of patients. *Significant difference between the means of the two groups $(p<0.05)$.

but not significant reduction in postoperative blood loss and donor blood transfusions.

Hemostasis is dependent on the function of the clotting system, the platelets, and the fibrinolytic system. Evidence for the pivotal role of platelet activation and fibrinolysis in hemostasis during CPB has been obtained by studies with platelet inhibitors such as prostacyclin ${ }^{12}$ and plasmin inhibitors such as aprotinin and tranexemic acid. ${ }^{13,14}$ Of the three main components of hemostasis, fibrinolysis might be of the greatest importance, because inhibitors of fibrinolysis have been most efficacious in reducing blood loss after $\mathrm{CPB} .{ }^{15,16}$

The failure to preserve hemostasis by heparin coating can be explained in various ways. In this study we demonstrated that fibrinolysis and platelet activation were not inhibited at all by the heparin coating, as shown by the generation of fibrin degradation products and by the platelet release products $\beta$-thromboglobulin and thromboxane $\mathrm{B}_{2}$. More specifically, hemostasis seemed in particular to be affected in the second period of $\mathrm{CPB}$, after aortic crossclamping. This enhanced effect is indicated by the observation in the present study that activation products from clotting and fibrinolysis were markedly generated after aortic crossclamping. That period during CPB seems to initiate more detrimental effects to the blood than the first period of $\mathrm{CPB}-$ during aortic crossclamping. After aortic crossclamping we found that the hemostatic mechanism was affected despite heparin coating, as 
indicated by similar postoperative bleeding times, blood loss, and donor blood transfusions in the two groups. These effects are thought to be due to reperfusion of the heart and lungs, to rewarming, and to the introduction into the systemic circulation of cardiotomy suction blood, known to incorporate many blood-activating products such as thrombin, plasmin, and fibrin degradation products. ${ }^{17}$ The result is activation of fibrinolysis and the clotting system and impairment of platelet function. Moreover, cardiotomy suction blood might have been activated additionally by the cardiotomy reservoir, the only uncoated component of the ECC. Past studies have shown that cardiotomy suction can destroy blood elements like platelets and can even obscure the improved hemocompatibility of a membrane oxygenator in comparison with that of a bubble oxygenator. ${ }^{18}$ On the other hand, nowadays the total amount of cardiotomy blood suction in routine CABG operations is small.

We conclude that Duraflo II heparin coating of a CPB circuit with our technique does partly prevent activation of the clotting system, but it does not reduce fibrinolysis and platelet activation. Consequently, it does not significantly reduce postoperative bleeding time, blood loss, and donor blood transfusions in routine CABG operations. Additional measures are required to protect the blood during CPB, in particular in the period after aortic crossclamping, when pulmonary circulation and reperfusion of the ischemic heart are reestablished and cardiotomy suction blood is introduced into the systemic circulation.

\section{REFERENCES}

1. Westaby S. Organ dysfunction after cardiopulmonary bypass: a systemic inflammatory reaction initiated by the extracorporeal circuit. Intensive Care Med 1987;13:89-95.

2. van Oeveren W, Wildevuur CRH, Kazatchkine MD. Biocompatibility of extracorporeal circuits in heart surgery. Transfusion Sci 1990;1 1:5-33.

3. Kirklin JK. Prospects for understanding and eliminating the deleterious effects of cardiopulmonary bypass [Editorial]. Ann Thorac Surg 1991;51:529-31.

4. Gu YJ, van Oeveren W, Akkerman C, Boonstra PW, Huyzen R, Wildevuur CRH. Reduction of the inflammatory response during cardiopulmonary bypass by the use of heparin-coated extracorporeal circuits. Ann Thorac Surg [In press].

5. Videm V, Mollnes TE, Garred P, Svennevig JL. Biocom- patibility of extracorporeal circulation. J THORAC CARDIOvasc SURG 1991;101:654-60.

6. Gu YJ, van Oeveren W, van der Kamp KWHJ, Akkerman C, Boonstra PW, Wildevuur CRH. Heparin coating of extracorporeal circuits reduces thrombin formation in patients undergoing cardiopulmonary bypass. Perfusion 1991;6:220-5.

7. Pasche B, Kodama K, Larm O, Olsson P, Swedenborg J. Thrombin inactivation on surfaces with covalently bonded heparin. Thromb Res 1986;44:739-48.

8. Tong SD, Rolfs MR, Hsu LC. Evaluation of Duraflo II heparin immobilized cardiopulmonary bypass circuits. ASAIO Trans 1990;36:M6546.

9. von Segesser LK, Weiss BM, Garcia E, von Felten A, Turina MI. Reduction and elimination of systemic heparinization during cardiopulmonary bypass. J THORAC CARDIOVASC SURG 1992;103:790-9.

10. Jansen NJG, van Oeveren W, vd Broek L, et al. Inhibition of reperfusion phenomena in cardiopulmonary bypass by dexamethasone. J Thorac Cardiovasc Surg 1991; 102:515-25.

11. Ivy AC, Nelson D, Bucher G. The standardization of certain factors in the cutaneous "venostasis" bleeding time technique. J Lab Clin Med 1940-1941;26:1812-22.

12. Rảdegran K, Arén C, Teger-Nilsson AC, Hall DP. Prostacyclin infusion during extracorporeal circulation for coronary bypass. J THORAC CARDIOVASC SURG 1982;83:20511.

13. van Oeveren W, Harder MP, Roozendaal KJ, Eijsman L, Wildevuur CRH. Aprotinin protects platelets against the initial effect of cardiopulmonary bypass. J THORAC CAR. DIOVASC SURG 1990;99:788-97.

14. Horrow JC, Hlavacek J, Strong MD, et al. Prophylactic tranexamic acid decreases bleeding after cardiac operations. J Thorac CardiovasC Surg 1990;99:70-4.

15. Editorial. Can drugs reduce surgical blood loss? Lancet 1988;1:155.

16. Edmunds LH Jr, Niewiarowski S, Colman RW. Invited letter concerning: Aprotinin. J THORAC CARDIOVASC SURG 1991;101:1103-4.

17. Tabuchi N, de Haan J, Boonstra PW, van Oeveren W. Activation of fibrinolysis in the pericardial cavity during cardiopulmonary bypass. $\mathrm{J}$ ThORAC CARDiovasC SURG [In press].

18. Boonstra PW, van Imhoff GW, Eijsman L, et al. Reduced platelet activation and improved hemostasis after controlled cardiotomy suction during clinical membrane oxygenator perfusions. J THORAC CARDIOVASC SURG 1985;89:900-6. 